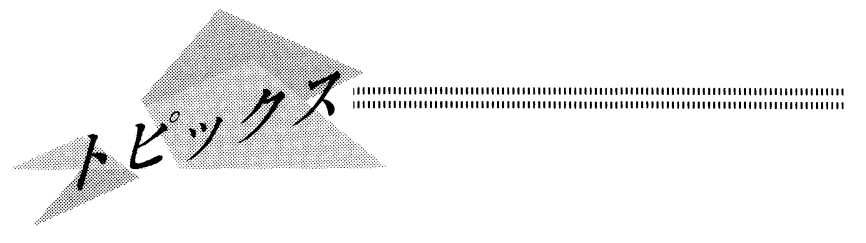

\section{環境浄化型 $\mathrm{TiO}_{2}$ 複合炭素材料}

\section{坂 志朗*}

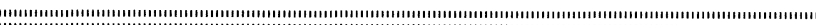

我々人類は，近年膨大な資源・エネルギーの消費によっ て, 大量生産, 大量消費, 大量廃棄の使い捨て社会をつくり 上げてきた．その結果，様々な物質が大気中に放出され，地 球の温暖化で代表される地球規模での環境破壊が徐々に進ん できた．居住面でも数十年前と比べると，格段に進歩した快 適な暮らしが可能となってきた．しかし，一方で木造建築住 宅の部材である合板, パーティクルボードや家具などにホル ムアルデヒド $(\mathrm{HCHO})$ 系接着剤が大量に使用され，接着の 反応阙与しなかった遊離の HCHO によるシックハウス症 候群などの疾病につながる室内環境污染が問題となっている.

この上らな環境污染物質に対し，木炭や活性炭は高い吸着 能を有することが古くから知られている。しかしながら，吸 着飽和するとそれ以上の吸着は望めず, 高温状態では脱着 し，環境污染物質を根本的に除去することはできない。一 方, アナターゼ型結晶構造を有する酸化チタン $\left(\mathrm{TiO}_{2}\right)$ は, 太陽光の紫外線によって励起され, 電子・正孔対が生じて, 酸化・還元反応が進行する. 正孔側では水からヒドロキシラ ジカルが生成するが，ヒドロキシラジカルの持つ強い酸化力 で $\mathrm{TiO}_{2}$ 付近存在する有機化合物などは水々二酸化炭素へ と分解されることが知られている.

このような $\mathrm{TiO}_{2}$ の光触媒活性を利用した空気污染物質の 除去㓮やセルフクリーニング効果, 抗菌効果, 脱臭効果など を有する新規な $\mathrm{TiO}_{2}$ 材料の開発が試みられてきた。しか ᄂ, $\mathrm{TiO}_{2}$ 単独では大気污染物質などの吸着力が弱く, 光触 媒活性を十分に誘引するには限度がある。そこで, 吸着剤と しての活性炭などと $\mathrm{TiO}_{2}$ とを混合した材料が考案され，有 害物質の吸着 $\rightarrow$ 分解(無害化)を可能とする材料が開発される に至っている. しかし，この物理的混合では，光分解反応の 活性種であるヒドロキシラジカルが吸着された有害物質と分 子レベルで共存しないため, 無害化効果が低く, 効果的な光 触媒活性が望めないのが現状である.

これらの背景を踏を兄, 我々は, 強い吸着能を有する木質 炭化物と $\mathrm{TiO}_{2}$ とをトポ化学的に複合させた新規な環境浄化 型木質炭素材料の創製を試及, 高効率飞大気污染物質を無害 化し得るメインテナンスフリーな新規な炭素材料を開発し

* 京都大学教授; 大学院エネルギー科学研究科 エネルギー社会 環境科学専攻 (

Carbonized $\mathrm{TiO}_{2}$ Woody Composites for Environmental Cleaning; Shiro Saka(Graduate School of Energy Science, Kyoto University)

Keywords: $\mathrm{TiO}_{2}$ gel, carbonized wood, composite, adsorption, photo-catalytic activity, anatase-form crystallites, formaldehyde, environmental cleaning, toxic substance

1999年12月 3 日受理
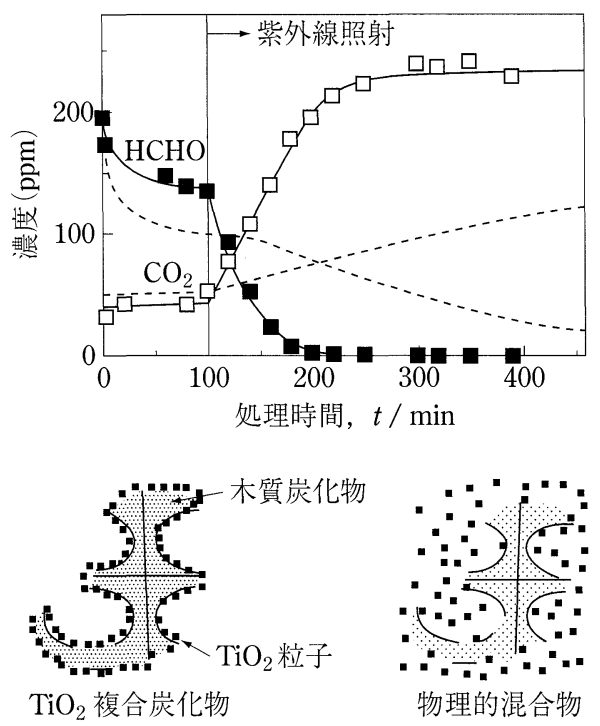

図 $1 \mathrm{TiO}_{2}$ 複合炭化物(実線) と物理的混合(破線)の HCHO 吸着打よび紫外線照射による光触媒分解 過程の比較.

た.すなわち，10年に及ぶゾルーゲル反応による木材の無機 質複合化による諸機能発現のトポ化学の研究(1)をもとに，木 材細胞壁中の $\mathrm{TiO}_{2}$ ゲルの分布が異なる種々の $\mathrm{TiO}_{2}$ 無機質 複合化木材を調製し，それらを400〜 $500^{\circ} \mathrm{C}$ の温度で熱処理 することにより， $\mathrm{TiO}_{2}$ 複合炭素材料を調製した. このこと により, 先の物理的混合とは異なった木材細胞と $\mathrm{TiO}_{2}$ ゲル とが分子レベルでトポ化学的に複合した $\mathrm{TiO}_{2}$ 複合炭素材料 の調製が可能となり，この温度領域で処理した複合体の木質 炭化部は, $\mathrm{HCHO}$, ベンゼン, クロロホルムなどの有害物 質を効率よく吸着し, $\mathrm{TiO}_{2}$ ゲルは光触媒活性の高いアナタ 一ゼ型に変換されることが明らかとなった.さらに, 種々の $\mathrm{TiO}_{2}$ 複合炭化物を評価した結果, $\mathrm{TiO}_{2}$ ゲルが木質炭化物表 面に複合したものが最も光触媒活性が大きいことが判明した.

この複合体を用いて, HCHOの吸着と紫外線照射 $(\lambda=$ $\left.365 \mathrm{~mm}, 0.5 \mathrm{~mW} / \mathrm{cm}^{2}\right)$ 後の光触媒活性による分解過程を評 価した結果を図 1 に示す. $\mathrm{CO}_{2}$ 濃度の変化から, $\mathrm{HCHO}$ 濃 度の初期（１00 min）での減少は炭化物による HCHO の吸 着によるものであり, 紫外線照射後 $(100 \sim 200 \mathrm{~min})$ は $\mathrm{CO}_{2}$ 濃度が増大していることから, $\mathrm{HCHO}$ の光触媒分解が効果 的に進んでいることを示している．比較のために示した波線 の結果は，木質炭化物とアナターゼ型 $\mathrm{TiO}_{2}$ 粒子を同条件で 別々に調製し，物理的に混合したもので，HCHO の吸着 $\rightarrow$ 分解が前者で極めて効率的に進行している様子が伺える.こ のことから, $\mathrm{TiO}_{2}$ 複合炭化物では, 木質炭化物の優れた吸 着能と $\mathrm{TiO}_{2}$ 粒子の高い光触媒活性による相乗効果が認めら れることがわかる.な拉, 熱処理により得られた炭化物は, この光触媒活性に対して安定であることも確認されている(2).

この新規な環境浄化型炭素材料は, HCHO のみでなく, ダイオキシンを初めとする多くの環境污染物質にも適用でき るものと期待される.

\section{文献}

(1) 坂 志朗: 材料, 48(1999), 575 .

(2) M. Doi, S. Saka, H. Miyafuji and D. A. I. Goring: Materials Sci. Res. Int., 6(2000), 15. 